\title{
EXTENDED SELF AND IDENTITY OVER TIME
}

\author{
Ana Grgić, Marina Novina
}

UDC 165.18

1Chalmers, D.

1Clark, A.

https://doi.org/10.32701/dp.23.1.4

Professional paper

Received: 05.09.2021

Accepted: 06.12.2021

\section{Abstract}

In this paper, we discuss the Extended Self Hypothesis proposed by Andy Clark and David Chalmers, and address the objection that the extended self lacks stability and continuity needed to be considered identical over time. We try to show that such an objection is untenable. We also discuss the view according to which another type of self, i.e., the narrative self, can also be seen as extended, and argue that stability and continuity of this type of self is also not threatened by its extension beyond the boundaries of person's body. Hence, at least as far as these types of self are concerned, there is no need to confine ourselves to the internalized self when thinking about the problems of personal identity.

KeYwords: David Chalmers, Andy Clark, extended self, identity over time, narrative self, self

\section{Introduction}

More than twenty years ago, in their now famous 1998 paper, "The Extended Mind," Andy Clark and David Chalmers proposed the so-called Extended Mind or Extended Cognition Hypothesis (EMH). Their main argument in support of the EMH concerns two people, Inga and Otto, who want to sepa-

+ The article is a revised and extended version of the paper presented at the international symposium held in Zagreb on 20th November 2020, titled 'The Impact of Technology on Human Being and Its Self-understanding'.

* Ana Grgić, PhD candidate, Faculty of Philosophy and Religious Studies, University of Zagreb, Jordanovac 110, 10000 Zagreb, Croatia. Research Assistant, Institute of Philosophy, Ul. grada Vukovara 54, 10 000, Zagreb, Croatia. E-mail: agrgic@ifzg.hr ORCID iD: https://orcid.org/ 0000-0003-0874-244X

* * Marina Novina, PhD, Assistant Professor of Philosophy, Faculty of Philosophy and Religious Studies, University of Zagreb, Jordanovac 110, 10000 Zagreb, Croatia.

E-mail: marina.novina@ffrz.unizg.hr

ORCID iD: http://orcid.org/0000-0001-7926-8330 
rately go to the Museum of Modern Arts, which is located on 53rd St. in New York. Inga has an internal, brain-bound belief about the address of the Museum, while Otto suffers from Alzheimer's disease, and he has to look up the address in his notebook. Thus, according to Clark and Chalmers, he has a notebook-bound belief about the address. While Inga has beliefs embedded in her memory, Otto's beliefs are embedded externally. Otto carries the notebook with him wherever he goes and relies on the information written in it. The notebook stores mental states that are outside Otto's head.

Clark and Chalmers argue that even though Otto's notebook-based beliefs and Inga's biologically based beliefs are not identical in kind, they are equal in their function: they are equal according to the role they have. Before she consulted her memory, Inga had a dispositional, or non-occurrent, belief about where the Museum was. Likewise, before he consulted his notebook, Otto had a dispositional, or non-occurrent, belief where the Museum was. As Clark and Chalmers put it, "in both cases the information is reliably there when needed, available to consciousness and available to guide action, in just the way we expect a belief to be" (Clark and Chalmers 1998, 13). Hence, Otto's notebook functions just as Inga's memory. It is constant and available at his disposal. When he consults his notebook, he, just like Inga, automatically gets his information. "Just like Inga ... Otto walked to 53rd St. because he wanted to go to the museum and believed (even before consulting his notebook) that it was on 53rd St. The functional poise of the stored information was, in each case, sufficiently similar ... to warrant similarity of treatment. Otto's long-term dispositional beliefs just weren't all in his head” (Clarke 2005, 2).

The conclusion is that cognition is beyond our skin and skull; or, in a catchier phrase, "cognitive processes ain’t (all) in the head" (Clark and Chalmers 1998, 8). In a nutshell, the basic idea of the EMH is that the artifacts, including various technological devices, as well as sociocultural environment, are parts of our cognitive processes that make up the human mind. For instance, the computer on which I am currently writing constitutes, together with my brain and hands, an integrated cognitive process in which I am engaged. I am linked to this computer in a two-way interaction, to the effect that this computer and I constitute a cognitive system in its own right. This computer has the same active causal role as my mind has, and coupled together, they govern my behavior. If you took away this computer, my performance would drop, just as it would if you removed a part of my brain. From this perspective, the mind is not just something in my head; when I use this computer, it goes external. Thus, according to Clark and Chalmers, there is no clear boundary between the mind and the world: the mind extends into the world and is inseparably connected with various artifacts. No one is complete in itself; rather, internal and external resources must be 
seen as integrated if we want to understand how we manage to accomplish our cognitive goals.

The EMH has profound implications for our understanding of the role of technology in our lives, and consequently, for human self-understanding. If technology is not just a tool with which we are dealing with the world, but literally a part of our minds, then this poses important questions about our identity as human beings, that is, about the sense in which we perceive ourselves as unified beings. In particular, the EMH challenges our traditional ideas about agency and responsibility. For, if the lines between mind and the world are blurred in the way in which the proponents of the EMH propose, then the very notion of agency as a way of influencing the world needs revision, and with it, our ideas about what constitutes our status as responsible beings. The acceptance of the EMH also poses some important questions about the way in which memory can be understood. For instance, if biological and non-biological memory are of the same kind, then non-biological memory is not just complementary to biological, and to understand how memory works, a hybrid science of memory is needed, which will encompass both biological and non-biological memory systems.

Therefore, it is not surprising that the EMH has drawn the attention of scholars from various disciplines (including philosophy, cognitive science, psychology, artificial intelligence, etc.), giving rise to a sort of a research program with many interesting results. In this paper, we will not discuss the merits and shortcomings of the hypothesis itself. We will focus instead on one of its corollaries, proposed originally in Clark and Chalmers (1998), according to which the human self is extended just as the mind is. While Clark has developed the EMH in various ways in his later writings, we will confine ourselves to his and Chalmers's position as it is stated in their paper from 1998, taking occasionally into consideration Clark's work from 2005 and 2007.

We will first (Section 2) address Clark's and Chalmers's argument for the view that the self should be seen as extended. Then (Section 3) we will discuss some practical and theoretical reasons for extending the self in the way proposed by Clark and Chalmers. While we doubt that the extension of the self will reflect in common usage and are reluctant to be convinced that people will abandon the customary way of referring to persons as nonextended entities, we believe that there is at least one theoretical reason to accept the idea of the extended self. In particular, we will discuss the objection, advanced by Lynne Rudder Baker (2009), that the extended self lacks stability and continuity needed to be considered identical over time. We will try to show that, given Clark's and Chalmers's understanding of the notion of the self, such an objection is untenable. Finally (Section 4), we will briefly discuss the view proposed by Richard Heersmink (2018 and 2020), accord- 
ing to which another type of self, i.e., the narrative self, can also be seen as an entity with fluid boundaries and thus extended. We will argue that stability and continuity of this type of self is also not threatened by its extension beyond the boundaries of person's body, albeit for different reasons than those adduced by Clark and Chalmers.

\section{The Argument for the Extended Self}

The notion of the self is introduced near the end of Clark's and Chalmers's (1998) in a form of the question being immediately answered:

What, finally, of the self? Does the extended mind imply an extended self? It would seem so. Most of us already accept that the self outstrips the boundaries of consciousness; my dispositional beliefs, for example, constitute in some deep sense part of who I am. If so, then these boundaries may also fall beyond the skin. The information in Otto's notebook, for example, is a central part of his identity as a cognitive agent. What this comes to is that Otto himself is extended system, a coupling of biological organism and external resources. To consistently resist this conclusion, we would have to shrink the self into a mere bundle of occurrent states, severely threatening its deep psychological continuity. Far better to take the broader view, and see agents themselves as spread into the world. (18)

At first glance, the idea seems clear. The self transcends consciousness. This is because consciousness includes only occurrent mental states, i.e., states of which the subject is currently aware, while the self includes dispositional, or non-occurrent mental states as well, i.e., states of which the subject is not currently aware, but which are somehow stored in her and available for use. Since the EMH claims that dispositional mental states such as dispositional memories and beliefs can be stored outside the boundaries of the subject's skin, it follows that her self can also be extended outside her skin. Otherwise, if we internalize the self and place it within the realm of consciousness, then we should consequently have to accept that the self is a mere bundle of here-and-now occurrent mental states. In other words, if internalized, the self begins to look like a Humean bundle of transitory perceptions, beliefs, and other mental states of which we are currently aware (cf. Hume 1978, 1.4.6.3). Hence, if we internalize the self, then there is no enduring self, and it can safely be eliminated. Thus, we should either accept the externalist notion of the self and accept that it is extended just like the mind is, or we should take an eliminative approach to the self. Clark and Chalmers opt for the former view, which is, as they say, "far better" (Clark and Chalmers 1998, 18).

This, in short, is Clark's and Chalmers's main argument in support of the Extended Self Hypothesis (ESH), as we may call it. The first thing we should consider is what they mean by "self," for one might think that the 
argument in support of ESH is nothing over and above the original argument in support of EMH. Just as the mind is seen as the bearer of occurrent and dispositional mental states in EMH, so is the self in ESH. We doubt, however, that Clark and Chalmers want to identify Otto with his mind. On the other hand, the argument in support of ESH need not work for those who assume that selves are biological organisms. They would say that when we refer to Otto, we refer to a biological organism or to an animal that he is, so that, for them, it does not follow that Otto himself is extended from the fact that Otto's mind is extended. ${ }^{1}$ Moreover, if Otto is essentially a biological organism, he cannot be non-biologically extended. There are other conceptions of the self for which the argument in support of the ESH will not work. It will not work, for instance, for the so-called minimal self, which is nothing more than "a consciousness of oneself as an immediate subject of experience, unextended in time” (Gallagher 2000, 15). Obviously, the minimal self so understood implies the presence of occurrent mental states only. Hence, the charitable reading of ESH should, first, assume that the self is not equated with the mind, and second, use the term 'self' in such a sense that it does not preclude it being extended. Clark and Chalmers do not argue that self is necessarily extended, but only that it can be.

As the above quotation from Clark and Chalmers shows, they are interested in two features of selves. First, selves are characterized as having cognitive abilities: they are "cognitive agents." Second, they enjoy "deep psychological continuity," i.e., they persist over time. Hence, the notion of self used in ESH is that of a cognitive enduring self. Both these features of the self are stressed in traditional Lockean accounts of the self and person. According to Locke, a person is "a thinking intelligent being, that has reason and reflection, and can consider itself as itself, the same thinking thing, in different times and places" (Locke 1975, 2.27.9). He also says that "Self is that conscious thinking thing ... which is sensible, or conscious of pleasure and pain, capable of happiness and misery, and so is concerned for itself as far as that consciousness extends" (Locke 1975, 2.27.17). Thus, according to Locke, persons are characterized by having cognitive abilities (reason, reflection, and thinking) and by enduring through time in virtue of the extension of consciousness, i.e., memory (leaving aside difficult issues in Lockean scholarship). Hence, we may tentatively assume that Clark and Chalmers use a broadly Lockean notion of the self. If we want to evaluate ESH, we should see if it works for this notion of the self.

Therefore, Otto himself should be seen as extended: when we refer to Otto, we actually refer to a system consisting of a biological organism and the notebook. The fact that Otto is such a system is the ground for his being 
a cognitive agent who retains his identity over time. Without his notebook, Otto is unable to act and does not endure through time.

ESH is not new. It was proposed by William James more than a hundred years ago. James says:

The Empirical Self of each of us is all that he is tempted to call by the name of me. But it is clear that between what a man calls me and what he simply calls mine the line is difficult to draw. We feel and act about certain things that are ours very much as we feel and act about ourselves. ... In its widest possible sense, however, a man's Self is the sum of all that he can call his, not only his body and his psychic powers, but his clothes and his house, his wife and children, his ancestors and friends, his reputation and works, his lands, and yacht and bank account. All these things give him the same emotions. If they wax and prosper, he feels triumphant; if they dwindle and die away, he feels cast down, not necessarily in the same degree for each thing, but in much the same way for all. ... An instinctive impulse drives us to collect property; and the collections thus made become, with different degrees of intimacy, parts of our empirical selves. (James 1890, 291-293, quoted in Heersmink 2020, 1)

James's and Clark and Chalmers's selves are similar as far as their ontological structure is concerned: James describes the self as a "sum," while Clark and Chalmers talk about a "system" and "coupling." The grounds for their extension, however, are quite different. On James's account, Otto's notebook will be a part of the sum called Otto or his self if Otto has a special kind of emotional attachment to his notebook. In Clark's and Chalmers's view, Otto and his notebook are inseparably linked as a unified whole on the grounds of their being parts of a cognitive system, to the extent that Otto would lose his identity if the notebook were destroyed. Presumably, the same does not hold for the notebook since it would continue to exist as the same notebook even after Otto's death. Hence, Clark's and Chalmers's ESH is more radical than James's, at least because, in their view, the very identity of a person depends on the continuous existence of items that make up a cognitive system.

\section{Extended Self, Stability, and Continuity}

ESH proposes a radical revision of our thinking of ourselves. Therefore, one might reasonably expect that there are strong practical and theoretical reasons for its acceptance. However, it is not immediately clear whether ESH has a potential to revise our usual practice in referring to persons. Clark suggests that it has, but does not provide the details:

It is our biological nature ... to be open to many forms of physical and cognitive hybridization. Some of these (I claim) may be so intimate as to effectively extend the thinking agent. All of them are crucial parts of the nested, iterated and ongoing process of cognitive re-creation that is the characteristic mark of hu- 
man intelligence. It is important that we develop an understanding of ourselves (both scientific and philosophical) that is adequate to this open-ended process of physical and cognitive re-creation. To do so means questioning the notions of mind and person as essentially biological, and recognizing the very large extent to which the commonplace identification of minds and persons with purely biological structures is itself what Locke (1694) termed a "forensic matter": a matter of legal and moral convenience more than metaphysics, and a convenience, moreover, that must become increasingly inconvenient as science and technology progress. (Clark 2005, 9-10)

For practical purposes, we distinguish Otto and his notebook. In moral and legal contexts, we hold Otto, rather than Otto-cum-his notebook, accountable for his actions, even though we can, if needed, take into consideration the fact that, properly speaking, he is just a part of a wider system. The name "Otto," regardless of the proper scientific or philosophical account of what or who Otto actually is, for us refers to Otto isolated from whatever he is merged with. The common usage serves pretty well the usual legal, moral, and social purposes, and it is not clear why it might become inconvenient to continue to treat persons, for everyday purposes, as non-extended creatures. Even if the self, in scientific and philosophical terms, goes "soft," as Clark puts it elsewhere $(2007,278)$, the common usage, we presume, will continue to regard it as being within the boundaries of the skin.

The more interesting and important reasons supporting $\mathrm{ESH}$ must, therefore, be theoretical. As we said, Clark and Chalmers view persons or selves as cognitive agents who endure through time. Assuming that the cognitive aspect of personhood is captured in the EMH, let us consider their endurance or identity over time.

Given the broadly Lockean commitments, we may take it that the extended person's identity over time is grounded in his or her psychological continuity, leaving aside the difficult question of its exact nature. Let us first consider a simple case. Suppose that there are three persons: Otto1 (Otto before the onset of Alzheimer), Otto2 (Otto who suffers from Alzheimer but taken without his notebook), and Otto3 (Otto who suffers from Alzheimer and uses his notebook). While it may be a difficult question whether Otto1 is identical to Otto2, we may assume that he is not since there is no sufficient psychological continuity between them. (After all, if we assume that they are identical, the introduction of the extended self would be pointless.) Is Otto3 identical to Otto1? If Otto3 started to record his beliefs in his notebook shortly after he became ill, or if his notebook stores sufficient amount of his beliefs such that his psychological continuity is secured, we may say that Otto1 and Otto3 are identical. His identity over time thus depends on an external artifact, and this seems to provide a strong reason in support of ESH. Thus, in this simple case, extending a self seems to secure its psychological continuity. 
ESH does not imply that human beings are necessarily extended, only that they can be. It is reasonable to suppose that for those selves that are extended, there was a time when they became such, just as Otto became extended when he started to use his notebook. Let us then consider a more complicated case, in which there is Inga1 (Inga before she became extended) and Inga2 (Inga extended). As extended, Inga is a part of a large cognitive system, which comprises, apart from her biological organism, her laptop, mobile phone, notebook, papers, books, photographs, other people, etc., since all of these store her dispositional mental states in a way described in EMH. Thus, Inga2 is a scattered object, having parts wherever these external objects are. Lynne Rudder Baker protests that such a scattered object cannot have ontological precedence over one of its alleged parts, Inga2, and claims that it is not clear what, if such a view is true, holds Inga2 together over time (Baker 2009, 647).

Leaving ontology aside, let us see what the problem with Inga2's identity is over time. The problem, as we see it, amounts to this: the system that makes up Inga2, supposing that it has no privileged part, is not identical over time because it is not stable. In the simple case of Otto and his notebook, there was first a cognitive system Otto1, which consisted of one part only (Otto's body), which then became a cognitive system Otto3, which consists of two parts (Otto's body and his notebook), and if Otto3's identity with Otto1' depends on their psychological continuity, ESH provides a good explanation. Otto3 is a stable object, regardless of the fact that it is scattered: the notebook is always available at his disposal. However, multiply scattered objects, such as Inga2 (and the vast majority of us), are not stable. They are more like fluid bundles. New parts are constantly added to them, and old parts are subtracted. Some of their parts last for a very short time; some are not easily available to Inga2 (more precisely, to her body); some are forgotten; etc. If such objects are not stable, the objection goes, then they cannot be continuous and identical over time.

But why assume that stability is needed for psychological continuity? There may be two reasons for this claim. First, one might insist that continuity requires an organizing or stabilizing principle, such that it holds the scattered parts of the system together. However, to insist that Inga2 lacks continuity because she lacks such a stabilizing principle is to beg the question against Clark's and Chalmers's ESH, since, as we have seen, their Lockean view of the self does not assume any such principle. Second, one might insist that Inga2 is not a sufficiently stable system, so that it cannot retain identity over time. Now, this would be true if Inga2 were a Humean bundle as it is described in a famous sentence: "I may venture to affirm of the rest of mankind, that they are nothing but a bundle or collection of different perceptions, which succeed each other with an inconceivable rapidity, and 
are in a perpetual flux and movement” (Hume 1978 1.4.6.4). However, Inga2 is not such a bundle, since she is not a system of occurrent, but of dispositional mental states. Even though the external resources in which they are stored are constantly changing, this does not threaten her psychological continuity. As opposed to the parts of the Humean bundle, the system that makes up Inga2 has a sufficient amount of relatively stable parts to secure the continuity of various stages of her life. The same holds for the relation she has to Inga1.

The opponent of the ESH might argue that a similar problem arises concerning Inga2's identity at a given time. If Inga2 asks herself, "Who am I?", her answer, whatever it is, is bound to be too broad and vague to be useful and informative, since there is no limit to the range of necessary externals. Perhaps more importantly, various artifacts and technological devices, as well as sociocultural environment, are something that we share with other members of our environment. Consequently, our selves are necessarily shared, rather than specifically individual. There is no definite and clearcut answer to the question, "Who am I?" posed by any member of the shared world of extended minds. However, this does not mean that such an answer can be provided if we resort to the internalized self. The opponent's argument assumes that the answer to the question, "Who am I?" must include the reference to everything that is confined to the boundaries of the self, which is absurd; it certainly cannot include everything that is going on in the person's brain. Besides, one might argue that the self is, for instance, essentially social, without presupposing anything about its status as extended or not extended. Therefore, given Clark's and Chalmers's broad Lockean perspective on the self, we don't think that the arguments concerning its identity are convincing.

\section{The Narrative Self Distributed}

After Clark's and Chalmers's introduction of the idea of the extended self, several scholars have argued that there are also other grounds on which selves can be seen as extended or distributed. ${ }^{2}$ We will conclude by briefly considering one such suggestion, recently proposed by Richard Heersmink (2018, 2020). Heersmink's view is relevant because he explicitly addresses the problem with stability and continuity, and provides a solution that is in an important respect different from the one discussed in the previous Section.

Heersmink operates with a different notion of self than Clark and Chalmers, although it also has Lockean roots. In his view, the self has a narrative 
structure, which means, in a nutshell, that each of us is a story told about oneself. The notion of the narrative self is most fully developed by Marya Schechtman (1996), who claims that "a person's identity is constituted by the content of her self-narrative, and the traits, actions, and experiences included in it are, by virtue of that inclusion, hers" (Schechtman 1996, 94, our italics). Self-narrative is unified by the memory of one's personal history, or autobiographical memory, which has a narrative structure: it is a subjective interpretation of important or self-defining events.

Heersmink's main idea is that autobiographical memories, and hence our narrative selves, are open to incorporate into themselves external objects and resources, including other people. Thus, the self-narrative we develop is built upon our interactions with external objects and people. Of special importance are the so-called evocative objects-artifacts such as photos, videos, souvenirs, furniture, letters, etc.-which are "physical objects or structures that in virtue of representational or non-representational properties evoke autobiographical memories” (Heersmink 2018, 1836). The fact that autobiographical memory is strongly dependent on such objects leads to the conclusion that it should be seen as distributed, both materially (across evocative objects) and socially (across other people). Hence, "[w]ho we are as persons or selves thus depends on and is partly constituted by a distributed network of environmental structures" (Heersmink 2018, 1830).

We have discussed the objection that the extended self lacks stability because it is fluid due to the constant change in the body's environment, and that, for the same reason, it lacks continuity, so that it is not clear how the fact that it is extended guarantees its deep psychological continuity as is claimed by Clark and Chalmers. Heersmink argues that stability and continuity for our narrative selves is provided by evocative objects. He gives an example of a person who keeps and uses a mug that she bought 20 years ago and that connects her present life with significant and emotionally laden events and episodes in her past (living in London, working in publishing, buying her first house) (Heersmink 2018, 1842; see Petrelli et al. 2008, 56). Heersmink argues that this example shows how evocative objects provide stability: some of them are durable, remain a part of our lives for long periods of time, and trigger or constitute autobiographical memories.

However, it is not true that every extended or distributed network includes an evocative object that guarantees stability: some networks contain more fixed elements than others. In this respect, a distributed narrative self is not necessarily more stable than Clark's and Chalmers's extended self. Besides, the system that makes up Inga2's self can include artifacts that are as stable as evocative objects: her mobile phone, for instance, can play the same role for her behavior as a cognitive agent as the mug in Heersmink's example does for his owner's life narrative. 
There is, however, an important difference between a distributed narrative self and Inga2's extended self. Heersmink says that continuity is provided by the narrative, which is the product of the agent herself (Heersmink $2018,1845,1846$ ); this is the standard view of the advocates of narrative self, for whom identity is grounded in narrative structure. For this reason, it can be said that narrative provides stability as well: an artifact is stable because it is a part of a narrative that stands out as dominant in person's history. The mug provides long-term stability not by itself, but by being the salient object in the narrative process. Thus, it is not quite true to say that "the network of evocative objects in which we are embedded provides stability and continuity for our autobiographical memory and narrative self" (Heersmink 2018, 1846). There is rather a mutual dependence: the narrative, on the one hand, ultimately provides the core stability and continuity, while the network of evocative objects, on the other, reinforces and sustains the evolving self. Thus, Heersmink's view is another example of the way in which self can go outside our skin and skull without losing its unity and continuity.

\section{Conclusion}

We have discussed two ways in which a human self can be seen as extended or distributed and have addressed the question of whether such views can preserve its continuity over time. We have tried to show that the identity of the extended self is not threatened whether it is understood as a broadly Lockean self or as the narrative self, albeit for different reasons. Hence, at least as far as these types of self are concerned, there is no need to confine ourselves to the internalized self when thinking about the problems of personal identity. ${ }^{3}$

\section{References}

Baker, Lynne Rudder. 2009. "Persons and the Extended-Mind Thesis." Zygon 44: 642-658.

Clark, Andy. 2007. "Re-inventing Ourselves: The Plasticity of Embodiment, Sensing, and Mind." Journal of Philosophy and Medicine 32: 263-282.

Clark, Andy. 2005. "Intrinsic Content, Active Memory and the Extended Mind.” Analysis 65: 1-11.

Clark, Andy, and David J. Chalmers. 1998. “The Extended Mind.” Analysis 58: 10-23.

3 Ana Grgić's contribution to this work has been supported by Croatian Science Foundation under the projects "Young Researchers' Career Development Project - Training New Doctoral Students" (DOK-2020-01-4459) and "Harm, Intentions and Responsibility" (UIP2017-05-4308). 
Gallagher, Shaun. 2000. "Philosophical Conceptions of the Self: Implications for Cognitive Science.” Trends in Cognitive Science 4: 14-21.

Heersmink, Richard. 2020. "Varieties of the Extended Self." Consciousness and Cognition 85: 1-12.

Heersmink, Richard. 2018. "The Narrative Self, Distributed Memory, and Evocative Objects.” Philosophical Studies 175: 1829-1849.

Hume, David. 1978. A Treatise of Human Nature, edited by Lewis Amherst SelbyBigge. 2nd ed., revised by P. H. Nidditch. Oxford: Clarendon Press.

James, William. 1890. The Principles of Psychology. New York: Dover.

Locke, John. 1975. An Essay Concerning Human Understanding, edited by P. H. Nidditch. Oxford: Clarendon Press.

Olson, Eric T. 2011. “The Extended Self.” Minds \& Machines 21: 481-495.

Petrelli, Daniela, Steve Whittaker, and Jens Brockmeier. 2008. "Autotopography: What Can Physical Mementos Tell Us About Digital Memories?" Proceedings of CHI 2008: 53-62.

Schechtman, Marya. 1996. The Constitution of Selves. Ithaca: Cornell University Press.

Sažetak

\section{PROŠIRENO JASTVO I IDENTITET KROZ VRIJEME} ANA GRGIĆ, MARINA NOVINA

U ovom članku raspravljamo o hipotezi proširenog jastva Andyja Clarka i Davida Chalmersa, a osobito o prigovoru prema kojemu proširenom jastvu nedostaje stabilnost i kontinuitet koji su potrebni da bismo ga smatrali identičnim kroz vrijeme. Pokušavamo pokazati da je taj prigovor neodrživ. Raspravljamo i o gledištu prema kojemu se drugi tip jastva, to jest narativno jastvo, također može shvatiti kao prošireno, i tvrdimo da stabilnost i kontinuitet toga tipa jastva također nisu ugroženi ako ga proširimo izvan granica čovjekova tijela. Stoga, barem što se tiče tih tipova jastva, kada razmišljamo o problemima osobnog identiteta, nije potrebno ograničiti se na internalizirano jastvo.

KLJUČNE RIJEČI: David Chalmers, Andy Clark, identitet kroz vrijeme, jastvo, narativno jastvo, prošireno jastvo

* Ana Grgić, doktorandica, Fakultet filozofije i religijskih znanosti Sveučilišta u Zagrebu, Jordanovac 110, 10000 Zagreb. Asistentica na Institutu za filozofiju, Ul. grada Vukovara 54, 10 000, Zagreb, Hrvatska. E-adresa: agrgic@ifzg.hr

ORCID iD: https://orcid.org/ 0000-0003-0874-244X

* * Doc. dr. sc. Marina Novina, Fakultet filozofije i religijskih znanosti Sveučilišta u Zagrebu, Jordanovac 110, 10000 Zagreb, Hrvatska. E-adresa: marina.novina@ffrz.unizg.hr ORCID iD: http://orcid.org/0000-0001-7926-8330 